\title{
INTRAARTICULAR STEROIDS IN TREATMENT OF JUVENILE IDIOPATHIC ARTHRITIS: A SINGLE CENTER EXPERIENCE
}

\author{
Cosickic Almira, ${ }^{1}$ Alic Adin, ${ }^{1}$ Suljendic Sanimir, ${ }^{1}$ Selimovic Amela, ${ }^{1}$ \\ Skokic Maida, ${ }^{2}$ Delibegovic Dina, ${ }^{1}$ Delibegovic Mirela ${ }^{3}$ \\ ${ }^{1}$ Clinic for Children's Diseases Tuzla, University Clinical Centre Tuzla, Bosnia and Herzegovina \\ ${ }^{2}$ Clinic for Internal Medicine Tuzla, University Clinical Centre Tuzla, Bosnia and Herzegovina \\ ${ }^{3}$ Clinic for Radiology and Nuclear Medicine, University Clinical Centre Tuzla, Bosnia and Herzegovina
}

Primljen/Received 17. 12. 2020. god.

Prihvaćen/Accepted 26. 02. 2021. god.

\begin{abstract}
Aim: To evaluate the therapeutic response to triamcinolone acetonide (TA) and triamcinolone hexacetonide $(\mathrm{TH})$ injections in the knee of children with JIA.

Material and methods: 46 joints of 42 children undergoing intra-articular injections were randomly treated with either TH or TA depending on the availability of the drug. A good response was defined as the decrease in articular score of $60 \%$ from the baseline and the ultrasound absence of synovitis. Clinical, laboratory variables were noted to examine possible predictive factors of the result.
\end{abstract}

Results: Of 42 children with JIA, the most common was the oligoarticular persistent form in 24 (57.1\%) children. Six-month remission was observed in $21.4 \%$ of children, TA vs. TH: $36.8 \%$ vs. $8.7 \%$ (p = 0.02 ). The absence of signs of knee inflammation within 12 months was found in $23.8 \%$ of children, after the application of TA vs. TH: $31.6 \%$ vs. $17.4 \%(p=0.28)$. However, long-term, a twenty-four-month remission was achieved in $52.4 \%$ of children - in twice as many children after TH $(69.9 \%)$ than after TA application $(31.6 \%)(p=0.03)$. A statistically significant correlation was observed between articular score values and duration of remission after TH application, $(r=0.56, p$ $=0.006 ; 95 \% \mathrm{CI}: 0.145-0.80$ ). Two children developed side effects in the form of subcutaneous atrophy at the site of injection, one girl developed transient crystal synovitis after TH applications.

Conclusion: This study has shown that intraarticular steroid injections are safe for the treatment of joint inflammation in JIA, and TA is effective in short-term follow-up where $\mathrm{TH}$ is an optimum choice in longterm follow-up.

Key words: Intraarticularsteroids, Children, Idiopathicarthritis.

\section{INTRODUCTION}

Juvenile idiopathic arthritis (JIA) is a chronic rheumatic disease of unknown cause, most common in childhood and a significant cause of disability in children (1). Various therapeutic options have been recommended to control inflammation and prevent permanent loss of joint function (2). The intraarticular steroids (IASs) are a commonly used option for the treatment in children with JIA with a small number of affected joints as well as an effective way to reduce and/or avoid the use of systemic drugs, to treat an arthritis flare in children already maintained on second-line agents $(3,4)$. The most commonly used corticosteroid preparations for IAS administration are long-acting corticosteroids, triamcinolone acetonide (TA), and triamcinolone hexacetonide (TH).

Aim: To evaluate the therapeutic response to TA and $\mathrm{TH}$ injections in the knee joints of children with arthritis.

\section{MATERIAL AND METHODS}

This retrospective-prospective study was conducted at the Department of Rheumatology, Immunology and Allergy of the Clinic for Children's Diseases, University Clinical Center (UCC) Tuzla in the period from January 2018 to December 2020. The medical records of children with JIA oligoarticular (persistent 
or extended) and polyarticular form of the disease who had received IAS injections were analyzed. The diagnosis and classification of JIA were made based on the classification and diagnostic criteria for JIA 2001 by the International League of Associations for Rheumatology (ILAR) (1). Inclusion criteria included the use of IAS injections either for an unsatisfactory response to NSAIDs, disease-modifying agents, and/or for persistent single-joint involvement. Exclusion criteria included failure to fulfill the diagnostic criteria, IAS treatment during the previous 12 months, and erosive joint changes on an X-ray. 42 children were included in the study, 12 boys and 30 girls; 19 children underwent therapy with TA and twenty-three with TH.

The following were analysed: gender, age at onset of JIA, the form of JIA, length of arthritis at the time of application of corticosteroids in the knee, values of inflammatory parameters, erythrocyte sedimentation rate (ESR), and C-reactive protein (CRP). The results were considered normal: ESR $\leq 15 \mathrm{~mm} / \mathrm{h}, \mathrm{CRP}<5$ $\mathrm{mg} / \mathrm{L}$. Clinical and ultrasound assessments of synovitis of the knee were performed before and then every 3 months until 24 months after the injection. The clinical assessment included an evaluation of the articular score used to determine the presence of swelling, limitation of range of movements, pain on passive movement, and joint warmth to touch (4). Each of these variables was measured on a scale ranging from 0 to 3 , and each variable was scored: 0 normal, 1 mild, 2 moderate, and 3 severe. The ultrasound examination of the knee assessed the presence of signs of synovitis: synovial thickening or enhancement, and effusion $(5,6)$. A good response to IAS injections was defined as the absence of signs of synovitis or if there was an articular score decrease of $60 \%$ when compared with the baseline. Relapse was defined as the reappearance of clinical or ultrasound signs of arthritis. The children's knee joints were injected with either $\mathrm{TA}$ or $\mathrm{TH}$; the choice of drug was dependent on the availability of $\mathrm{TH}$ during the study period. The procedure was performed with ultrasound guidance. One hour before the procedure $\mathrm{Eu}$ tectic lidocaine/prilocaine cream (EMLA) was applied to the skin above the joints and half an hour before the procedure children received oral midazolam. TA or TH at the dose of $20 \mathrm{mg}, 30 \mathrm{mg}$, and $40 \mathrm{mg}$ of steroids were administered in the knee joint for children weighing < $20 \mathrm{~kg},>20 \mathrm{~kg}$, and $>40 \mathrm{~kg}$, respectively.

\section{Ethics Statement}

The study protocol was approved by the Ethics Committee of UCC Tuzla. Informed consent was signed by the parents of all participants.

\section{Statistical analysis}

Statistical data analysis was conducted using the biomedical software application "MedCalc for Windows, Version 15.11.4" (Med Calc Software, Ostend, Belgium). The variables with distorted distribution were shown with the median as a measure of the central value. The $\chi 2$-test, the Mann-Whitney $U$ test was used to test the statistical significance of the difference between the samples. Spearman's correlation coefficient was used to assess the correlation of variables. The difference was considered significant when $p<$ 0.05 .

\section{RESULTS}

Five out of 47 children with JIA met the exclusion criteria, i.e. 3 children had received IAS treatment during the previous 12 months, 1 child had erosive findings on joint $\mathrm{X}$-ray, and for 1 child parents did not consent to participate in the study. The median age of 42 children was 7.1 years (minimum and maximum from 2.1 to 6.8 years). The median age at disease onset was 5.3 years (minimum and maximum from 2.1 to 6.8 years). The most common was an oligoarticular persistent form of JIA observed in 24 (57.1\%) children, while $3(7.1 \%)$ children had polyarticular rheumatic factor (RF) + JIA. 46 knee joints were injected with either TA or TH, and in 4/42 (9.5\%) children steroids were injected in both knees (TA in 1, TH in 3 children). The characteristics of the two treatment groups are summarized in Table 1.

All children injected with TA and TH initially improved, and five children had a prompt release of joint contractures, two with oligoarticular extended, and three children with a polyarticular form of diseases. One boy with oligoarticular extended JIA relapsed one month after injections of $\mathrm{TH}$, who developed the clinical and ultrasound characteristics of synovitis. The number of children with a sustained response of 24 months was significantly higher with $\mathrm{TH}$ than with TA: $69.6 \%$ vs $31.6 \%(p=0.03)$ (Table 1$)$. Six joints were still in remission after the 24 month follow-up period, 2 joints after TA and 4 after TH injections, but without statistical significance $\mathrm{p}=0.52$.

Spearman's correlation coefficient was done to assess the correlation between articular score, the value of CRP, ESR, disease duration, and remission duration of synovitis in both groups of children, with TA and $\mathrm{TH}$ injections. A statistically significant correlation was observed only between articular score values and duration of remission after TH application $(\mathrm{r}=0.56$, $\mathrm{p}=0.006$; $95 \% \mathrm{CI}$ : $0.145-0.80$ ), while no statistically 
Table 1. Clinical characteristics of the two treatment groups of children with JIA*

\begin{tabular}{|c|c|c|c|}
\hline & $\begin{array}{c}\text { TA } \\
(n=19)\end{array}$ & $\begin{array}{c}\text { TH } \\
(n=23)\end{array}$ & $\mathbf{p}$ \\
\hline \multicolumn{4}{|l|}{ Gender N (\%) } \\
\hline Girls & $13(68.4)$ & $17(74.0)$ & \multirow{2}{*}{0.47} \\
\hline Boys & $6(31.6)$ & $6(26.0)$ & \\
\hline $\begin{array}{l}\text { Age years, median } \\
\text { (minimum-maximum) }\end{array}$ & $\begin{array}{c}6.8 \\
(5.3-9.2) \\
\end{array}$ & $\begin{array}{c}7.2 \\
(6.2-9.0) \\
\end{array}$ & 0.3 \\
\hline $\begin{array}{l}\text { Age disease onset (years, median) } \\
\text { (minimum-maximum) }\end{array}$ & $\begin{array}{c}4.6 \\
(3.4-5.2) \\
\end{array}$ & $\begin{array}{c}5.8 \\
(2.1-6.6) \\
\end{array}$ & 0.13 \\
\hline \multicolumn{4}{|l|}{ Form of disease $\mathbf{N}(\%)$} \\
\hline Oligoarticular persistent form & $9(47.4)$ & $15(65.2)$ & 0.24 \\
\hline Oligoarticular extended form & $2(10.5)$ & $3(13.0)$ & 0.06 \\
\hline Polyarticular $\mathbf{R F}^{\dagger}+$ form & $1(5.3)$ & $2(8.8)$ & 0.66 \\
\hline Polyarticular RF- form & $7(36.8)$ & $3(13.0)$ & 0.71 \\
\hline $\begin{array}{l}\text { Disease duration months, median } \\
\text { (minimum-maximum) }\end{array}$ & $\begin{array}{c}14.0 \\
(3-28)\end{array}$ & $\begin{array}{c}17.0 \\
(2-27)\end{array}$ & 0.28 \\
\hline \multicolumn{4}{|l|}{$\begin{array}{l}\text { Articular score at baseline N (\%) } \\
\geq 5 \\
4 \\
3\end{array}$} \\
\hline $\begin{array}{l}\text { ESR }{ }^{*} \mathbf{m m} / \mathbf{h}, \text { median } \\
\text { (minimum-maximum) }\end{array}$ & $\begin{array}{c}15 \\
(6-23) \\
\end{array}$ & $\begin{array}{c}20 \\
(11-35) \\
\end{array}$ & 0.002 \\
\hline $\begin{array}{l}\text { CRP§ mg/dl, median } \\
\text { (minimum-maximum) }\end{array}$ & $\begin{array}{c}7.8 \\
(2.1-24.8)\end{array}$ & $\begin{array}{c}17.4 \\
(10.5-28.1)\end{array}$ & 0.01 \\
\hline Injected joins N (\%) & $20(43.5)$ & $26(56.5)$ & \\
\hline NSAID" N (\%) & $9(47.4)$ & $16(69.6)$ & 0.25 \\
\hline NSAID+MTX ${ }^{* *}$ N (\%) & $8(42.1)$ & $5(21.8)$ & 0.15 \\
\hline MTX+TNFi ${ }^{\dagger} \mathbf{N}(\%)$ & $2(10.5)$ & $2(8.7)$ & 0.15 \\
\hline \multicolumn{4}{|c|}{ Duration of response after IAS injections N (\%) } \\
\hline 3 week & - & $1(4.3)$ & \\
\hline 6 months & $7(36.8)$ & $2(8.7)$ & 0.02 \\
\hline 12 months & $6(31.6)$ & $4(17.4)$ & 0.28 \\
\hline 24 months & $6(31.6)$ & $16(69.6)$ & 0.03 \\
\hline
\end{tabular}

*juvenile idiopathic arthritis; ${ }^{\dagger}$ rheuma factor; ${ }^{*}$ erythrocyte sedimentation rate, ${ }^{\S} \mathrm{C}$ reactive protein, ${ }^{\|}$antinuclear antibody, ${ }^{\mathrm{q}} \mathrm{N}$ Non-steroidal anti-inflammatory drug, ${ }^{* *}$ methotrexate, ${ }^{\dagger}$ tumor necrosis factor inhibitor.

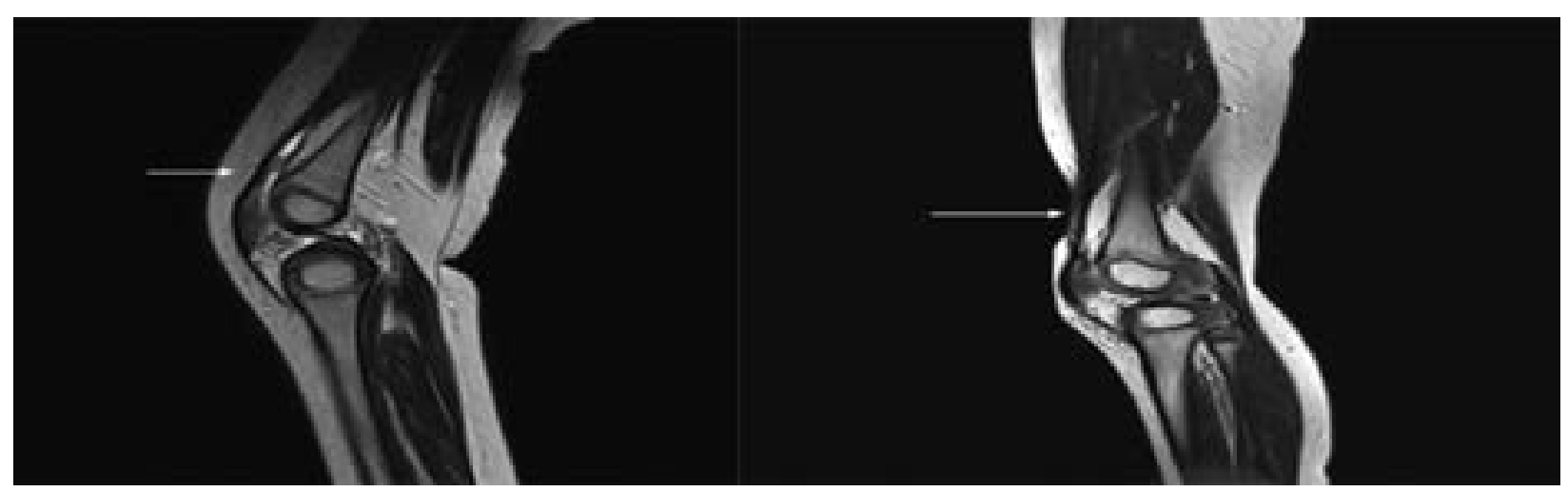

Figure 1A-B. Magnetic resonance imaging T2 sagittal section, a knee of 2 year old girl. A: Normal subcutaneous tissue before corticosteroid application (arrow);

$B$ : atrophic subcutaneous tissue 2 months after application of corticosteroids (arrow) 
significant correlations were found between other analysed variables.

Two children, one in each group, developed side effects in the form of subcutaneous atrophy at the site of injection (Fig. 1). Resolution of subcutaneous atrophy was noted after 9 months in one child; while 14 months after the steroid injections, at the time of writing the article, there was no complete resolution of subcutaneous atrophy in the other child. One girl developed transient crystal synovitis following the application of TH, which spontaneously subsided within 14 days.

\section{DISCUSSION}

Intraarticular steroid usage is a safe treatment option in children with JIA $(1,5,6)$. The intra-articular approach delivers a high concentration of corticosteroids to the primary site of pathology, where among other things down-regulates immunological processes production of proinflammatory cytokines (7). Ravelli et al. (8) reported that $52 \%$ of children achieved remission in injected joints, similar to Neidel et al. (9) and Cuncha et al. (10) who reported full remission of joint inflammation in $58-82 \%$ and more than $50 \%$ of large joints of children enrolled in their study. As TH has a lower solubility compared to TA, its absorption from the injected joint is slower, thereby maintaining synovial levels for a longer period, which may account for its enhanced efficacy $(2,11,12)$. The results obtained by Zulian et al. (13) clearly showed that after 6 months $81.4 \%$ of joints injected with $\mathrm{TH}$ and $53.3 \%$ of joints injected with TA had no sign of inflammation. The six-month response rate after TH was similar to that reported in other studies, ranging from $67.6 \%$ to $82 \%$, and regarding TA, researchers found a response rate lower $(11,14)$. However, Ravelli et al. (15), as well as Lapore et al. (16), observed a six-month arthritis remission in $69 \%$ and $68 \%$ of children after TA application. Our results were somewhat in accordance with the findings of the aforementioned studies. The shortterm-six-month remission was observed in a large number of children following the application of TA than of TH. However, we noted twenty-four-month arthritis remission in $31.6 \%$ of children after TA, and in just about twice as many children after TH, $69.6 \%(\mathrm{p}=$ 0.03 ). Six joints were still in remission after the twenty-four-month follow-up, four joints after $\mathrm{TH}$, and two after TA injections. In a randomised controlled trial of TH versus TA in oligoarthritis, Martini et al. (16) observed that a significant improvement in the TH group was maintained over two years of follow-up. Neidel et al. (9) achieved two years remission in $78 \%$ of children after TH injections. Results obtained by some other researchers were similar, which showed that $\mathrm{TH}$ was more effective than TA in long-term follow-up $(8,10$, 13). The studies showed thus longer response duration after IAS injections in children who developed arthritis at a younger age and had shorter disease duration at the time of IAS application, with higher activity of arthritis and in children with an oligoarticular form of the disease (13-16). Our findings were in accordance with that, the most frequent form of arthritis was oligoarticular in children enrolled in our study was oligoarticular, the median age was 7.1 years, median disease duration was 11 months (minimum and maximum from 2-28 months); in most children the activity of arthritis was moderate, and perhaps that explains why long term remission was achieved after IAS injections in a significant number of children included in our study. However, Leow et al. (2) and Zulian et al. (13) emphasised the difference between outcomes after the application of TA and $\mathrm{TH}$, but they also did not find any difference in markers of inflammationor articular score. Our findings were somewhat different - considering the influence of the variables such as articular score, the value of ESR, CRP, and duration of disease - we only found a significant positive correlation between disease duration and remission duration in the group of children with $\mathrm{TH}$. It seems that heterogeneity of the JIA children with different subtypes of arthritis may account for this different result. Studies showed an overall favorable adverse effect profile.Iatrogenic septic arthritis is very rare and can be avoided with aseptic precautionssince transient crystal synovitis is self-limited without any intervention (13-16). The most frequent adverse effects are atrophic skin changes at the site of injection, particularly of smaller joints such as wrists, ankles, and interphalangeal joints. Subcutaneous atrophy is a well-recognised adverse effect with resolution after two to four years $(17,18)$. However, recent studies have shown a relatively high incidence of osteochondral lesions, and repetitive steroid injections need to be considered an associated risk factor $(19,20)$. In our study adverse effects of IAS in the form of subcutaneous atrophy at the site of injection developed in two children (remission occurred after nine months in one child, while the subcutaneous tissue was not completely recovered in another child); one girl developed transient crystal synovitis after $\mathrm{TH}$ applications, who underwent multiple IAS injections and spontaneous resolution of crystals occurred.

\section{The Limitations of the Study}

We presented the clinical outcomes of a small number of children in a short period for the assessment 
of the final outcome. This can be evaluated many years after, not just after an initial follow-up.

\section{CONCLUSION}

This study has shown that IAS is safe for the treatment of joint inflammation in JIA, and TA is effective in short-term follow-up but TH is an optimum choice in long-term follow-up.

\section{Abbreviations}

CRP - C reactive protein

EMLA - Eutectic lidocaine/prilocaine cream

ESR - erythrocyte sedimentation rate

IAS - Intraarticular steroids

ILAR - International League of Associations for Rheumatology

JIA - juvenile idiopathic arthritis

MTX - Methotrexate
NSAID - Non-steroidal anti-inflammatory drug

RF - Rheuma factor

TA - triamcinolone acetonide

TH - triamcinolone hexacetonide

TNFI - Tumor necrosis factor inhibitor

\section{Conflict of interest}

All of the authors declare that they read and approved the final version of the manuscript. Additionally, there are no conflicts of interest in connection with this paper, and the material described is not under publication or consideration for publication elsewhere.

Funding: None

\section{Licensing}

This work is licensed under a Creative Commons Attribution 4.0 International (CC BY 4.0) License.

\title{
Sažetak
}

\section{INTRAARTIKULARNI STEROIDI U LEČENJU IDIOPATSKOG JUVENILNOG ARTRITISA: ISKUSTVO JEDNOG CENTRA}

\author{
Ćosičkić Almira, ${ }^{1}$ Alić Adin, ${ }^{1}$ Suljendić Sanimir, ${ }^{1}$ Selimović Amela, ${ }^{1}$ \\ Skokić Maida, ${ }^{2}$ Delibegović Dina, ${ }^{1}$ Delibegović Mirela ${ }^{3}$ \\ ${ }^{1}$ Clinic for Children's Diseases Tuzla, University Clinical Centre Tuzla, Bosnia and Herzegovina \\ ${ }^{2}$ Clinic for Internal Medicine Tuzla, University Clinical Centre Tuzla, Bosnia and Herzegovina \\ ${ }^{3}$ Clinic for Radiology and Nuclear Medicine, University Clinical Centre Tuzla, Bosnia and Herzegovina
}

Cilj: proceniti terapijski odgovor nakon aplikacije injekcije triamcinolon acetonida (TA) i triamcinolon heksacetonida $(\mathrm{TH}) \mathrm{u}$ kolena dece $\mathrm{s}$ juvenilnim idiopatskim artritisom (JIA). Materijal i metode: U četrdeset šest zglobova od 42 dece aplikovan je TH ili TA u zavisnosti od dostupnosti leka. Dobar odgovor na aplikaciju steroida je definisan kao smanjenje zglobnog skora za $60 \%$ u odnosu na početnu vrednost, odsustvo ultrazvučnih karakteristika sinovitisa, dok su kliničke i laboratorijske varjable razmatrane kao prediktorni faktori ishoda. Rezultati: Najčešća forma JIA bila je oligoartikularna perzistenta u 24/42 (57.1\%) dece. Šestomesečna remisija zabeležena je za $21.4 \%$ dece, nakon primene TA vs TH $36.8 \%$ vs $8.7 \%(\mathrm{p}=0.02)$. Odsustvo znakova upale kolena tokom 12 meseci imalo je $23.8 \%$ dece, nakon primene TA vs TH $31.6 \%$ vs $17.4 \%(p=0.28)$. Dugoročna dvadesetčetvoromesečna remisija ostvarena je u $52.4 \%$ dece, u više od dvostrukog broja dece nakon TH (69.9\%) nego nakon aplikacije TA $(31.6 \%)(p=0.03)$. Statistički značajna korelacija primećena je između vrednosti rezultata zglobnog skora i trajanja remisije nakon primene $\mathrm{TH}(\mathrm{r}=0.56$, $\mathrm{p}=0.006 ; 95 \%$ CI: 0.145-0.80). Dvoje dece razvilo je neželjene efekte u obliku atrofije potkožnog tkiva na mestu aplikacije, jedna devojčica je razvila prolazni kristalni sinovitis nakon primene TH. Zaključak: Naše skromno iskustvo pokazuje da je intraartikularna primena steroida siguran pristup lečenja upale zglobova dece s JIA, te da je TA efikasniji u kratkoročnom, ali da je TH optimalniji izbor u dugoročnom praćenju.

Ključne reči: Intraartikularni steroidi, deca, idiopatski artritis.

\section{REFERENCES}

1. Petty RE, Southwood TR, Baum J, Bhettay E, Glass DN, Manners P, et al. Revision of the proposed classification criteria for juvenile idiopathic arthritis: Durban, 1997. J Rheumatol. 1998; 25(10): 1991-4.

2. Leow OM, Lim LK, Ooi PL, Shek LP, Ang EY, Son MB. Intra-articular glucocorticoid injections in patients with juvenile idiopathic arthritis in a Singapore hospital. Singapore Med J. 2014; 55(5): 248-52. doi: 10.11622/smedj.2014066.

3. Jennings H, Hennessy K, Hendry GJ. The clinical effectiveness of intra-articular corticosteroids for arthritis of the lower limb in juvenile idiopathic arthritis: a systematic review. 
Pediatr Rheumatol Online J. 2014; 12:23. doi: 10.1186/15460096-12-23.

4. Bloom BJ, Alario AJ, Miller LC. Intra-articular corticosteroid therapy for juvenile idiopathic arthritis: report of an experiential cohort and literature review. Rheumatol Int. 2011; 31(6): 749-56. doi: 10.1007/s00296-010-1365-x.

5. D’Agostino MA, Terslev L, Aegerter P, Backhaus $\mathrm{M}$, Balint $\mathrm{P}$, Bruyn GA, et al. Scoring ultrasound synovitis in rheumatoid arthritis: a EULAR-OMERACT ultrasound taskforce-Part 1: definition and development of a standardized, consensus-based scoring system. RMD Open. 2017; 3(1): e000428. doi: 10.1136/rmdopen-2016-000428.

6. Ruth NM, Passo MH. Juvenile idiopathic arthritis: management and therapeutic options. Ther Adv Musculoskelet Dis. 2012; 4(2): 99-110. doi: 10.1177/1759720X11413630.

7. Zulian F, Martini G, Gobber D, Agosto C, Gigante C, Zacchello F. Comparison of intra-articular triamcinolone hexacetonide and triamcinolone acetonide in oligoarticular juvenile idiopathic arthritis. Rheumatology (Oxford) 2003; 42(10): 1254-9. doi: 10.1093/rheumatology/keg358.

8. Ravelli A, Davì S, Bracciolini G, Pistorio A, Consolaro A, van Dijkhuizen EHP, et al. Intra-articular corticosteroids versus intra-articular corticosteroids plus methotrexate in oligoarticular juvenile idiopathic arthritis: a multicentre, prospective, randomised, open-label trial. Lancet. 2017; 389(10072): 909-16. doi: 10.1016/S0140-6736(17)30065-X.

9. Neidel J, Boehnke M, Küster RM. The efficacy and safety of intraarticular corticosteroid therapy for coxitis in juvenile rheumatoid arthritis. Arthritis Rheum. 2002; 46(6): 1620-8. doi: 10.1002/art.10313.

10. Cuncha ALG, Miotto E Silva VB, Osaku FM, Niemxeski LB, Furtado RN, Natour J et al. Intra-articular injections in patients with juvenile idiopathic arthritis: factor associated with a good response. Rev Bras Reumatol Engl Ed. 2016; 56(6): 490-6. doi: 10.1016/j.rbre.2016.01.001.

11. Beukelman T, Patkar NM, Saag KG, Tolleson-Rinehart S, Cron RQ, DeWitt EM, et al. 2011 American College of Rheumatology recommendations for the treatment of juvenile idiopathic arthritis: initiation and safety monitoring of therapeutic agents for the treatment of arthritis and systemic features. Arthritis Care Res (Hoboken). 2011; 63(4): 465-82. doi: 10.1002/acr.20460.

12. Brown GT, Wright FV, Lang BA, Birdi N, Oen K, Stephens D, et al. Clinical responsiveness of self-report func- tional assessment measures for children with juvenile idiopathic arthritis undergoing intraarticular corticosteroid injections. Arthritis Rheum. 2005; 53(6): 897-904. doi: 10.1002/art.21599.

13. Zulian F, Martini G, Gobber D, Plebani M, Zacchello F, Manners P. Triamcinolone acetonide and hexacetonide intra-articular treatment of symmetrical joints in juvenile idiopathic arthritis: a double-blind trial. Rheumatology (Oxford) 2004; 43(10): 1288-91. doi: 10.1093/rheumatology/keh313.

14. Ravelli A, Lattanzi B, Consolaro A, Martini A. Glucocorticoids in pediatric rheumatology. Clin Exp Rheumatol. 2011; 29(Suppl 68): S148-52.

15. Lepore L, Del Santo M, Malorgio C, Presani G, Perticarari S, Prodan M, et al. Treatment of juvenile idiopathic arthritis with intra-articular triamcinolone hexacetonide: evaluation of clinical effectiveness correlated with circulating ANA and T gamma/delta + and B CD5+ lymphocyte populations of synovial fluid. Clin Exp Rheumatol. 2002; 20(5): 719-22.

16. Martini G, Gobber D, Agosto C, Vianello A, Zulian F.. Comparison between intraarticular triamcinolone hexacetonide and acetonide in oligoarticular JIA. Ann Rheum Dis. 2001; 60(Suppl 11): ii, 12.

17. Lanni S, Bertamino M, Consolaro A, Pistorio A, Magni-Manzoni S, Galasso R, et al. Outcome and predicting factors of single and multiple intra-articular corticosteroid injections in children with juvenile idiopathic arthritis. Rheumatology (Oxford). 2011; 50(9): 1627-34. doi: 10.1093/rheumatology/ ker165.

18. Papadopoulou C, Kostik M, Gonzalez-Fernandez MI, Bohm M, Nieto-Gonzalez JC, Pistorio A. et al. Delineating the role of multiple intra-articular corticosteroid injections in the management of juvenile idiopathic arthritis in the biologic era. Arthritis Care Res (Hoboken). 2013; 65(7): 1112-20. doi: 10.1002/acr.21947.

19. Heidt C, Grueberger N, Grisch D, Righini-Grunder F, Rueger M, Ramseier L. . The assessment of steroid injections as a potential risk factor for osteochondral lesions in children with juvenile idiopathic arthritis. Cartilage. 2020; doi:1947603520961173.

20. Kubo H, Oommen PT, Hufeland M, Heusch P, Laws HJ, Krauspe R, et al. Osteochondritis dissecans shows a severe course and poor outcome in patients with juvenile idiopathic arthritis: a matched pair study of 22 cases. Rheumatol Int. 2018; 38(9): 1705-12. doi: 10.1007/s00296-018-4100-7.

\section{Correspondence to/Autor za korespondenciju}

\section{Adin Alić}

Mehmedalije Maka Dizdara 35, 75000 Tuzla,

Bosna and Herzegovina

Tel: +38761649654

Email: adin.alic@ukctuzla.ba 